\title{
THE “CONDUCT AND EFFECTS" OF TRANSNATIONAL SECURITIES FRAUD: AN ANALYSIS OF THE EXTRATERRITORIAL APPLICATION OF THE EXCHANGE ACT ANTIFRAUD PROVISIONS AFTER DODD-FRANK
}

\author{
Eric Pennesi*
}

\section{INTRODUCTION}

Since it was recently addressed by both the Supreme Court and Congress, ${ }^{1}$ one could logically assume that the extraterritorial application of the antifraud provisions of United States securities laws, specifically the Securities Exchange Act of $1934,{ }^{2}$ would be well settled. However, as is often the case, although theoretically logical, this assumption is realistically inaccurate. ${ }^{3}$ The passing of the Dodd-Frank Wall Street Reform and Consumer Protection Act ("Dodd-Frank" or the "Act"), including its clauses regarding extraterritorial application of the

\footnotetext{
* J.D. Candidate, May 2012, University of Pittsburgh School of Law.

${ }^{1}$ See Morrison v. Nat'l Austl. Bank, __ U.S.__ (2010), 130 S. Ct. 2869 (2010); Dodd-Frank Wall Street Reform and Consumer Protection Act of 2010, Pub. L. No. 111-203, §§ 929P, 929Y, 2010 U.S.C.C.A.N. (124 Stat.) 1376, 1862-65, 1871 [hereinafter Dodd-Frank Act] (amending scattered sections of 15 U.S.C.).

${ }^{2} 15$ U.S.C. $\S 78$.

${ }^{3}$ See, e.g., Richard W. Painter et al., When Courts and Congress Don't Say What They Mean: Initial Reactions to Morrison v. National Australia Bank and to the Extraterritorial Jurisdiction Provisions of the Dodd-Frank Act, 20 MinN. J. INTL. L. 1 (2011); Daniel Zinn, Commentary: "Foreign-Cubed" Redux, TRAders' Magazine OnLINE News (Sept. 22, 2010), http://www.tradersmagazine.com/news/ sec-foreign-cubed-106356-1.html?zkPrintable=true.
} 
antifraud provisions of the Securities Exchange Act of 1934 (the "Exchange Act"), has cast into doubt the applicable standards and principles for primarily foreign securities suits. ${ }^{4}$ As a result, investors, public companies, and courts are left to sift through the inconsistencies to determine the legal standards applicable both currently and in the future. As the frequency with which transnational securities transactions are conducted continues to increase, the importance of discerning the laws applicable to the parties involved has become undeniable.

One particular type of securities action at the forefront of the debate is known as a "Foreign-Cubed" ("F-Cubed") action. These suits, typically structured as class actions, arise when classes consisting of foreign investors bring suit against foreign issuers concerning securities listed on and purchased from foreign markets. ${ }^{5} \mathrm{~F}$ Cubed securities classes typically attempt to utilize the limited connection of the claim to the United States in order to obtain a judgment under the country's oftenfavorable securities laws. ${ }^{6}$ F-Cubed actions are classified as private actions, as they are initiated directly by the investors. ${ }^{7}$ In contrast, public actions are initiated directly by the government, characteristically by the Securities Exchange Commission (the "SEC" or "Commission"), but occasionally by other facets of government such as the Department of Justice (DOJ). ${ }^{8}$ In practice, this distinction between public and private suits has become the vital differentiating characteristic in treatment by the courts and Congress. ${ }^{9}$

The Supreme Court attempted to clarify disagreement among the lower courts regarding extraterritoriality of the securities laws in Morrison v. National Australia Bank. ${ }^{10}$ This solution was short-lived, however, as less than a month later the passage of Dodd-Frank and its related provisions allegedly altered the Supreme

\footnotetext{
${ }^{4}$ Painter, supra note 3, at 1-2.

5 Danielle Kantor, The Limits of Federal Jurisdiction and the F-Cubed Case: Adjudicating Transnational Securities Disputes in Federal Courts, 65 N.Y.U. ANN. SuRV. AM. L. 839, 841-42 (2010).

${ }^{6}$ Id. at 844-46; see also Morrison, 130 S. Ct. 2869.

${ }^{7}$ See Kantor, supra note 5.

${ }^{8}$ Id. at 853 n.66 (citing Tellabs, Inc. v. Makor Issues \& Rights, Ltd., 551 U.S. 308, 313 (2007) (“[The Supreme Court] has long recognized that meritorious private actions to enforce federal antifraud securities laws are an essential supplement to criminal prosecutions and civil enforcement actions brought, respectively, by the Department of Justice and the Securities and Exchange Commission (SEC).")).

${ }^{9}$ See Morrison, 130 S. Ct. 2869; Dodd-Frank Act $\S$ 929P, 929Y.

${ }^{10} 130$ S. Ct. 2869.
} 
Court's ruling. ${ }^{11}$ While some disagreement exists concerning Dodd-Frank's actual effect on public suits, ${ }^{12}$ this question is ancillary to the issue of its effect on private suits. ${ }^{13}$ In order to fully understand the consequences of this recent legislation on the current state of the law and its extraterritorial application in private suits, it is helpful to first consider the standard applicable to public suits-although this standard is not necessarily binding on private suits. ${ }^{14}$ Dodd-Frank requires that the SEC conduct a study regarding the appropriate standard for private suits and report the results to Congress, which must then determine whether or not to draft legislation to address the issue. ${ }^{15}$

At the outset of this note, Part II provides a brief overview of the Exchange Act provisions at issue and the treatment of transnational securities actions by courts prior to the Morrison decision. Part III discusses the Morrison decision, specifically the reasoning behind the approach chosen by the Court and the competing claims at the time of the decision. In Part IV of this note, the provisions of Dodd-Frank relating to extraterritorial application of United States securities laws are analyzed and discussed in light of their potential impact to this issue. Included in Part IV is a general analysis of the dispute regarding the effect of Dodd-Frank on public suits, the treatment of these suits moving forward, and the effect (or lack thereof) of this dispute on the law governing private suits. Part V discusses the future of extraterritorial application of the securities laws in private suits. Specifically, an analysis of the method of SEC investigation is presented, followed by a discussion of the likely result of that investigation. While this discussion illustrates that a strong possibility exists that the SEC will recommend

\footnotetext{
${ }^{11}$ Dodd-Frank Act $\S$ 929P, 929Y.

${ }^{12}$ Section 929P explicitly provides jurisdiction to United States courts for public actions, but many believe that the courts already had jurisdiction over such actions, and that Dodd-Frank does not solve the problem that prevented the courts from hearing these actions - the merits of such claims. Compare, e.g., Painter, supra note 3 (discussing concerns with the effects of $\S 929 \mathrm{P}$ ), and George T. Conway, Extraterritoriality After Dodd-Frank, HARV. L. SCH. Forum On CORP. GOVERNANCE \& Fin. REg. BlOG (Aug. 5, 2010, 8:58 AM), http://blogs.law.harvard.edu/corpgov/2010/08/05/extraterritoriality-afterdodd-frank/ (claiming that $\S 929 \mathrm{P}$ has no practical effect as written), with Zinn, supra note 3 (acknowledging § 929P as instituting a new standard for public actions and ignoring concerns regarding effectiveness), and Matthew Bender Treatise on Securities Practice, 1-1 Securities Practice Guide $\S 1.01$ (Lorraine Massaro \& Robert P. Zinn eds., 2010).

${ }^{13}$ Commentators appear to agree on the fact that the rule announced in Morrison will stand for private suits until such time as the SEC announces its findings under § 929Y and Congress chooses whether to act. Zinn, supra note 3.

${ }^{14}$ See id.

${ }^{15}$ Dodd-Frank Act $§ 929 Y(c)$.
} 
the current "transactional" test as the method of dealing with private actions, Part V concludes with a proposal in support of extending the standard applicable to public actions, the modified "conduct and effects" standard, to private actions. Lastly, Part VI summarizes the state of the law and the theories advanced within this note.

\section{The Securities Exchange ACt of 1934 And Pre- MORRISON APPROACHES TO EXTRATERRITORIAL APPLICATION}

The Exchange Act, in relevant part, prohibits "manipulative or deceptive devices" related to the purchase or sale of securities. ${ }^{16}$ Section10(b) of the Exchange Act prohibits devices that violate SEC rules and regulations, specifically Rule 10b-5, which regulates actions that have the effect of defrauding investors or misstating or omitting material facts regarding the purchase or sale of securities. ${ }^{17}$ Certain provisions of the Exchange Act have been interpreted to suggest extraterritorial application, but there is no explicit language authorizing such reach. ${ }^{18}$ When also considering the general presumption that U.S. law does not

\footnotetext{
16 "It shall be unlawful for any person, directly or indirectly, by the use of any means or instrumentality of interstate commerce ... or of any facility of any national securities exchange ... [t]o use or employ, in connection with the purchase or sale of any security registered on a national securities exchange or any security not so registered ... any manipulative or deceptive device ... in contravention of such rules and regulations as the [SEC] may prescribe ...." Securities Exchange Act of $1934 \S 10$ (b), 15 U.S.C. § $78 \mathrm{j}(\mathrm{b})(2006)$.

${ }^{17}$ Rule 10b-5 makes it "unlawful for any person, directly or indirectly, by the use of any means or instrumentality of interstate commerce, or of the mails or of any facility of any national securities exchange, (a) To employ any device, scheme, or artifice to defraud, (b) To make any untrue statement of a material fact or to omit to state a material fact ..., or (c) To engage in any act, practice, or course of business which operates ... as a fraud or deceit upon any person, in connection with the purchase or sale of any security.” 17 C.F.R. $\S 240.10 b-5$ (2011).

${ }^{18}$ See Securities Exchange Act $\S 10(b) ; 17$ C.F.R. $\S 240.10 b-5$. The Court in Morrison discussed previous approaches of lower courts based on certain language of the antifraud provisions that were said to imply extraterritorial application, but the majority rejected such implications and relied on the lack of an explicit grant of extraterritorial application by Congress. $130 \mathrm{~S}$. Ct. at 2882. The Morrison concurrence was more accepting to such an implication because "[t]he text and history of $\S 10$ (b) are famously opaque on the question of when, exactly, transnational securities frauds fall within the statute's compass." Id. at 2888 (Stevens, J., concurring).
} 
apply without its borders, ${ }^{19}$ the extraterritorial reach of these basic antifraud provisions in transnational securities actions has been the subject of much debate. ${ }^{20}$

Prior to the Morrison case, lower courts utilized various approaches to determine whether these antifraud provisions should apply to private transnational securities actions, many of which appeared to be primarily foreign-based claims. ${ }^{21}$ The most common, and most often cited, of these approaches were the "conduct" test and the "effects" test. ${ }^{22}$ Developed by the Second Circuit, these tests were generally justified by the view that $\S 10$ (b) was silent as to extraterritorial reach, so the question became whether a court believed that the disputes were of great enough importance to the United States to justify the investment of resources by the legal system. ${ }^{23}$

Under the effects test, a court looked to whether the "wrongful conduct had a substantial effect in the United States or upon United States citizens." ${ }^{24}$ Under the conduct test, a court looked to whether the wrongful conduct- - such as fraud, deceit, or misstatement of material facts - occurred in the United States. ${ }^{25}$ When the harmed investors were foreign (as in F-Cubed actions), the level of conduct was required to be more than "mere preparation" for wrongful conduct that occurs

${ }^{19}$ EEOC v. Arabian Am. Oil Co., 499 U.S. 244, 248 (1991) (“[There is a] longstanding principle of American law 'that legislation of Congress, unless a contrary intent appears, is meant to apply only within the territorial jurisdiction of the United States."') (quoting Foley Bros. v. Filardo, 336 U.S. 281, 285 (1949)); see also Morrison, 130 S. Ct. at 2877.

${ }^{20}$ See, e.g., Morrison, 130 S. Ct. at 2877-83.

${ }^{21}$ See, e.g., SEC v. Berger, 322 F.3d 187, 192-93 (2d Cir. 2003), abrogated by Morrison, 130 S. Ct. 2869; Zoelsch v. Aurthur Andersen \& Co., 824 F.2d 27, 31-33 (D.C. Cir. 1987), abrogated by Morrison, 130 S. Ct. 2869; Leasco Data Processing Equip. Corp. v. Maxwell, 468 F.2d 1326 (2d Cir. 1972), abrogated by Morrison, 130 S. Ct. 2869; Schoenbaum v. Firstbrook, 268 F. Supp. 385, 392 (S.D.N.Y. 1967), aff'd in part, rev'd in part, 405 F.2d 215 (2d Cir 1968).

${ }^{22}$ Morrison, 130 S. Ct. at 2878-80.

${ }^{23}$ See id. at 2879; Bersch v. Drexel Firestone, Inc., 519 F.2d 974, 985 (2d Cir. 1975) ("When, as here, a court is confronted with transactions that on any view are predominantly foreign, it must seek to determine whether Congress would have wished the precious resources of United States courts and law enforcement agencies to be devoted to them rather than leave the problem to foreign countries."), abrogated by Morrison, 130 S. Ct. 2869.

${ }^{24}$ Berger, 322 F.3d at 192-93.

${ }^{25}$ Id. at 193. 
PAGE

outside the country, and the conduct was required to be shown to have directly caused the loss to the investors. ${ }^{26}$

These tests were generally viewed as the most accurate method of determining the policy-based issue of congressional intent regarding extraterritorial application of the antifraud provisions of the Exchange Act. ${ }^{27}$ Generally, other circuits agreed with the Second Circuit's approach, albeit with various alterations. ${ }^{28}$ However, the conduct and effects tests were not without their shortcomings. The tests did not remain independent of each other and were typically melded together into one general test considering factors regarding both conduct and effects, which made for difficult application. ${ }^{29}$ Complicating the problem was that no two cases could be analyzed the same way, since certain factors carried different weight in different situations, a dilemma that even the Second Circuit, which developed the tests, recognized. ${ }^{30}$ This unpredictability, coupled with the aforementioned difficulty in application, demonstrated that the current state of the law was far from ideal. Some sort of resolution was necessary, and the ultimate issue would no doubt primarily rest on the balance between the standard presumption against extraterritoriality for United States statutes and the judicial power to interpret congressional legislation. ${ }^{31}$

\section{ThE SUPREME COURT STEPS IN: MORRISON V. NATIONAL AUSTRALIA BANK}

Morrison v. National Australia Bank was a rather typical private transnational securities action: a primarily foreign dispute with some level of connection to the United States where the plaintiff class is attempting to receive compensation for violations of U.S. securities laws. The plaintiff class consisted of Australian

26 Morrison, $130 \mathrm{~S}$. Ct. at 2879. In comparison, where American investors are harmed, "merely preparatory" acts were found sufficient, and "it was enough that acts of 'material importance' performed in the United States 'significantly contributed' to that result[.]" Id.

${ }^{27}$ See id. at 2878-80; Berger, 322 F.3d at 192-93.

${ }^{28}$ Morrison, 130 S. Ct. at 2880. See also Zoelsch v. Aurthur Andersen \& Co., 824 F.2d 27, 30-33 (D.C. Cir. 1987) (criticizing the Second Circuit's approach, but ultimately accepting the conduct and effects tests based on the expertise in securities law of the Second Circuit), abrogated by Morrison, $130 \mathrm{~S}$. Ct. 2869.

${ }^{29}$ Morrison, 130 S. Ct. at 2879 (explaining that the Second Circuit refused to keep the two tests distinct in an effort to get a better picture of United States involvement).

${ }^{30} I d$. at 2879 .

${ }^{31} I d$. at $2880-83$. 
investors who purchased shares of National Australia Bank's stock on a foreign exchange, making the suit an F-Cubed action. ${ }^{32}$ The dispute arose over alleged fraud committed by National Australia Bank and a mortgage servicing business it had acquired, HomeSide Lending, in valuating certain assets. ${ }^{33}$ While some amount of wrongful conduct was found to have occurred in the United States, ${ }^{34}$ the Court found the antifraud provisions of the Exchange Act (and consequently the related SEC rules) inapplicable. ${ }^{35}$ This finding against extraterritorial application abrogated the Second Circuit's conduct and effects tests and instituted a "transactional" test in their wake. ${ }^{36}$ In doing so, the Court stressed that the presumption against extraterritoriality controls in the absence of express contrary language contained in the statute. ${ }^{37}$ In adopting the transactional test, the Court found that the Exchange Act was enacted to control the purchase and sale of securities, and thus the focus of the analysis for such situations should be on the place of purchase and sale rather than the place of deceptive conduct. ${ }^{38}$ Under the test, §10(b) (and consequently Rule 10b-5) applies only to "securities listed on domestic exchanges[] and domestic transactions in other securities." ${ }^{39}$ In Morrison, the Court found that National Australia Bank did not list its stock on United States stock exchanges and that the Australian investors neither purchased nor sold the

${ }^{32} I d$. at 2876.

${ }^{33} \mathrm{Id}$. at $2875-76$.

${ }^{34}$ HomeSide Lending was originally a Florida-based company, and its headquarters remained there after National Australia Bank purchased the company. Id. at 2875. The alleged fraud in the case was based on the post-acquisition misstatement of HomeSide's mortgage servicing assets. Id. at 2876. While some of this activity undoubtedly occurred in Florida, the actual reporting and dissemination of information to the investors occurred in Australia. Id.

${ }^{35} I d$. at 2888 .

${ }^{36} I d$. at 2886. In addition, the Court rejected the United States' proposed "significant and material" standard for the conduct test for public actions and "direct injury" standard for the conduct test for private actions. Id.; see also Brief for the United States as Amicus Curiae Supporting Respondents at 67; Morrison v. Nat'l Austl. Bank, 130 S. Ct. 2869 (2010) (No. 08-11091) [hereinafter Brief for the United States] (discussing these proposed standards and their proper application to Morrison).

${ }^{37}$ Morrison, 130 S. Ct. at 2883 . The Court initially framed the issue in a different light than previously believed. This aspect of the decision continues to play a significant part in the current debate regarding the effectiveness of the relevant Dodd-Frank provisions. The Court held that, contrary to the Second Circuit's approach, the issue of extraterritorial application of the antifraud provisions in transnational securities actions is a question of the merits of such a claim, not the jurisdiction over the claim. Id. at $2876-77$.

${ }^{38}$ Morrison, 130 S. Ct. at 2884.

${ }^{39} I d$. 
U N I V E R S I T Y O F P I T T S B U R G H L A W R E V I E W

PAGE

stock in the United States, rendering the antifraud provisions inapplicable. ${ }^{40}$ The Court hailed this new standard as a way of eliminating the uncertainty that the application of the conduct and effects tests had created in the outcomes of transnational securities actions while maintaining both the congressional intent of the antifraud provisions and the canon of statutory interpretation against extraterritoriality. ${ }^{41}$

\section{Not So FAST: Congress Addresses the MATter (SOMEWHAT) DIRECTLY}

The ink barely had time to dry on the Court's Morrison opinion, an exercise of judicial authority intended to set the standard for debate regarding transnational securities actions, before Congress decided to take up the issue directly. Less than a month after the Morrison decision came down, Dodd-Frank passed Congress and was signed into law by President Barack Obama. ${ }^{42}$ The broad scope of the Act extends investor protections and institutes measures for reform of many publicly traded companies. ${ }^{43}$ More importantly for purposes of the issue at hand, the secondary provisions of $\S \S 929 \mathrm{P}$ and $929 \mathrm{Y}$ of the Act are aimed at expanding extraterritorial application of the antifraud provisions contained in the securities laws. ${ }^{44}$ Section 929P directly proscribes the standard for extraterritorial application in public actions, ${ }^{45}$ while $\S 929 \mathrm{Y}$ provides guidance for the determination of the standard for private actions. ${ }^{46}$

${ }^{40} I d$. at 2888 .

${ }^{41} I d$. at 2884-88. For a discussion of the claimed and actual effects of the Morrison approach, see Scott Hirst, U.S. Supreme Court Rejects "Foreign Cubed" Class Actions, HARV. L. SCH. FORUM ON CORP. GOVERNANCE \& FIN. REG. BlOG (June 25, 2010, 9:23 AM), http://blogs.law.harvard.edu/corpgov/2010/ 06/25/u-s-supreme-court-rejects-foreign-cubed-class-actions/.

${ }^{42}$ See Morrison, 130 S. Ct. 2869 (dated June 24, 2010); Dodd-Frank Act (dated July 21, 2010); Matthew Bender Treatise on Securities Practice, supra note 12 (Dodd-Frank signed into law by President shortly after).

${ }^{43}$ Matthew Bender Treatise On Securities Practice, supra note 12.

${ }^{44}$ Zinn, supra note 3.

${ }^{45}$ Section 929P(b) of the Dodd-Frank Act provides jurisdiction to district courts for actions by the SEC or the United States "alleging a violation of [the antifraud provisions] involving - (1) conduct within the United States that constitutes significant steps in furtherance of the violation, even if the securities transaction occurs outside the United States and involves only foreign investors; or (2) conduct occurring outside the United States that has a foreseeable substantial effect within the United States."

${ }^{46}$ Section 929Y of the Dodd-Frank Act requires the SEC to "solicit public comment and thereafter conduct a study" to determine the extent the antifraud provisions of the Securities Exchange Act should extend to private actions covering the same situations as $\S 929 \mathrm{P}(\mathrm{b})$. 
The express grant of jurisdiction to United States courts contained in $\S 929 \mathrm{P}$ for public actions is undisputed. However, the effect of this provision is far from certain. On its face, the provision appears to permit claims in situations that fall under what amounts to the modified "conduct and effects" test proposed for public actions in the United States' amicus brief in Morrison. ${ }^{47}$ Application of this standard to public actions only is in line with what the SEC proposed to Congress while Dodd-Frank was being developed, suggesting the maintenance of a higher standard for private actions. ${ }^{48}$ The intent of Congress to achieve this result for public actions appears in the legislative history. ${ }^{49}$ The dispute arises from many who claim that the language of $\S 929 \mathrm{P}$, which grants jurisdiction to the district courts, renders the provision essentially ineffective. This stance is based on the Court's finding in Morrison that the issue of extraterritoriality was a question of merits, not jurisdiction. ${ }^{50}$ A prominent firm involved in the Morrison litigation explained this view in a memorandum circulated shortly after Dodd-Frank's enactment, stating that Dodd-Frank does not address the substantive reach of the

\footnotetext{
${ }^{47}$ Much of the discussion regarding Dodd-Frank has treated the $\S 929 \mathrm{P}$ standard as a return to the original conduct and effects tests, but an analysis of the language of the standard reveals striking similarity to the test proposed by the United States in Morrison. Compare Brief for the United States, supra note 36, at 7 (" $[\mathrm{W}]$ hen a transnational securities fraud involves significant and material conduct in the United States ... the SEC can bring an enforcement action.”), with Dodd-Frank Act § 929P(b)(1) (authorizing an SEC action when "conduct within the United States that constitutes significant steps in furtherance of the violation"); see also Zinn, supra note 3 (describing the language of $\S 929 \mathrm{P}(\mathrm{b})(1)$ as "very much in line with the SEC's original proposal in Morrison"); contra Morrison, 130 S. Ct. at 2879 (describing the previous conduct test as "whether the wrongful conduct occurred in the United States" (quoting SEC v. Berger, 322 F.3d 187, 192-93 (2d Cir. 2003), abrogated by Morrison, 130 S. Ct. 2869)).

${ }^{48}$ See Zinn, supra note 3; Painter, supra note 3, at 15. For a discussion of this "dual jurisdictional" standard, see Brief for the United States, supra note 36, at 25-30. See also Kantor, supra note 5, at 87475 (discussing this approach).

49 "This bill's provisions concerning extraterritoriality, however, are intended to rebut [the Morrison transactional test] by clearly indicating that Congress intends extraterritorial application in cases brought by the SEC or the Justice Department. Thus, the purpose of the language of $\S 929 \mathrm{P}(\mathrm{b})$ of the bill is to make clear that in actions and proceedings brought by the SEC or the Justice Department, the specified provisions of ... the Exchange Act ... may have extraterritorial application ... irrespective of whether the securities are traded on a domestic exchange or the transactions occur in the United States, when the conduct within the United States is significant or when conduct outside the United States has a foreseeable substantial effect within the United States." 156 CONG. REC. H5237 (daily ed. June 30, 2010); see also Painter, supra note 3, at 19 (discussing Congressional intent to provide extraterritorial application for public actions); Zinn, supra note 3 (claiming that such an intent can be found in the legislative history); Conway, supra note 12 (noting the Dodd-Frank drafters' "extra-statutory statements" regarding § 929P).

${ }^{50}$ Morrison, 130 S. Ct. at 2877.
} 
PAGE

antifraud provisions, thus rendering $§ 929 \mathrm{P}$ ineffective and inconsequential. ${ }^{51}$ Others have chosen to adopt the stance that $\S 929 \mathrm{P}$ does provide extraterritorial application in public actions, emphasizing the clear congressional intent over this allegedly ineffective plain meaning of the provision. ${ }^{52}$

While the debate regarding public actions could be resolved by a variety of methods, the most likely being judicial decisions interpreting $\S 929 \mathrm{P}$ or congressional action altering the language or effect of the provision, the future of private actions under $\S 929 \mathrm{Y}$ is at once more and less discernable. What appears certain is that the SEC study mandated by $\S 929 \mathrm{Y}$ will be conducted with the goal of determining the most appropriate standard for extraterritoriality in private actions. Dodd-Frank sets the guidelines for the content of this study, which should encompass the scope of private actions that should be permitted under the standard, the implications of the application of such a standard on international comity, ${ }^{53}$ the economic costs and benefits of the potential standards, and the possibility of adopting a narrower standard than that applied under $\S 929 \mathrm{P}^{54}$ Also, Dodd-Frank includes a requirement that this SEC study be submitted to Congress within eighteen months of the passage of the Act, at which time the recommendations discerned from the study must also be made. ${ }^{55}$ Barring action by the Court in contravention of its stance in Morrison, the standard for extraterritorial application of the antifraud provisions for private actions will remain the transactional test until this study has been concluded and Congress determines whether to institute an alternative standard. ${ }^{56}$

\footnotetext{
${ }^{51}$ Conway, supra note 12. For more information regarding the basis of this stance, see Painter, supra note 3, at 14-24; Zinn, supra note 3; Steven M. Davidoff, How Porsche May Outmaneuver a Securities Suit, N.Y. Times DeAlBOOK (Oct. 22, 2010, 11:05 AM), http://dealbook.blogs.nytimes.com/2010/10/ 22/how-porsche-may-outmaneuver-a-securities-suit/.

${ }^{52}$ See Zinn, supra note 3; Painter, supra note 3.

${ }^{53}$ Comity is defined as "[a] practice among political entities (as nations, states, or courts of different jurisdictions), involving esp. mutual recognition of legislative, executive, and judicial acts." BLACK's LAW DiCTIONARY 303 (9th ed. 2009).

54 "The study shall consider and analyze, among other things-(1) the scope of such a private right of action, including whether it should extend to all private actors or whether it should be more limited to extend just to institutional investors or otherwise; (2) what implications such a private right of action would have on international comity; (3) the economic costs and benefits of extending a private right of action for transnational securities frauds; and (4) whether a narrower extraterritorial standard should be adopted.” Dodd-Frank Act § 929Y(b).

${ }^{55} I d . \S 929 \mathrm{Y}(\mathrm{c})$.

${ }^{56}$ Zinn, supra note 3. See also Painter, supra note 3.
} 
The immediate discussion concerning the extraterritoriality provisions of Dodd-Frank has been dominated by the dispute regarding public actions and $\S 929 \mathrm{P} .^{57}$ There is no doubt that this focus has been well placed, considering $\S 929 \mathrm{P}$ purports to have an immediate effect on transnational securities actions. In comparison, the potential effects of $\S 929$ Y likely will not even begin to be realized until the eighteen-month period allotted for the SEC study has concluded. Even then, the very real possibility exists that the standard will remain unaltered and Morrison will continue to control. However, the importance of whatever standard is deemed appropriate to transnational securities claims by investors cannot be denied. If the Morrison interpretation stands, numerous investors will be left without redress in American courts, which are often the only forum in which such actions are available.$^{58}$ Public companies could possibly be emboldened with the idea of a lower level of accountability for fraudulent behavior. ${ }^{59}$ In contrast, a broader standard for extraterritoriality in private suits would likely create considerable costs for United States investors, businesses, and the court system. ${ }^{60}$ Additionally, as one quoted reaction accurately portrayed, "the prospect of [the $\S 929 \mathrm{Y}]$ study 'scares a . . number of foreign capitals,' which 'fear seeing the United States become' a global 'financial policeman' through class-action lawsuits. ${ }^{" 61}$ With such high stakes, the potential outcome and effects of $\S 929 \mathrm{Y}$ deserve more consideration than currently available. The remainder of this note attempts to provide such consideration of $\S 929 \mathrm{Y}$ through an analysis of the standard likely to be recommended by the SEC after its study, as well as a discussion of why this standard is not in fact the best solution to the issue of extraterritoriality of the antifraud provisions in private actions.

${ }^{57}$ See, e.g., Zinn, supra note 3; Painter, supra note 3; Conway, supra note 12; Davidoff, supra note 51.

${ }^{58}$ See Letter from Ohio Pub. Emps.' Ret. Sys. et al. to Elizabeth M. Murphy, Sec'y, SEC, at 6 (Feb. 18, 2011) [hereinafter Ohio Public Employees' Retirement System Comments] ("[Under the transactional test,] an entire class of investors would be carved out of the securities laws and reserved to the SEC."), http://www.sec.gov/comments/4-617/4617-16.pdf.

${ }^{59}$ See Morrison, 130 S. Ct. at 2895 (Stevens, J., concurring) (giving a hypothetical example with significant fraudulent conduct and effects in the United States that could not be pursued through private action under the transactional test); Letter from Nat'l Ass'n of S'holder \& Consumer Attorneys to Elizabeth M. Murphy, Sec'y, SEC, at 15-18 (Feb. 18, 2011) [hereinafter NASCAT Comments], http://www.sec.gov/comments/4-617/4617-18.pdf.

${ }^{60}$ See Letter from U.S. Chamber of Commerce to Elizabeth M. Murphy, Sec'y, SEC 22-24 (Feb. 18, 2011) [hereinafter U.S. Chamber of Commerce Comments], http://www.sec.gov/comments/4-617/461737.pdf.

${ }^{61}$ Conway, supra note 12 (partially quoting a Le Monde report). 
U N I V E R S I T Y O F P I T T S B U R G H L A W R E V I E W

PAGE

\section{What to Do with Private Actions: The Possible StANDARDS AND THE MEANINGFUl DifFERENCE BETWEEN WHAT IS LIKELY AND WHAT IS BEST}

\section{A. Background: A Better Feel for Private Transnational Securities Actions}

In order to fully understand the debate on the appropriate standard for private transnational securities actions, it is important to realize the nature of these claims. In the transnational context, private claims arise in F-Cubed and "F-Squared" situations. ${ }^{62}$ Although not expressly authorized by the Exchange Act, a general private action has been implied from $\S 10 \mathrm{~b}$ and Rule $10 \mathrm{~b}-5 .{ }^{63}$ Due to the implied nature of this right of action, courts have read additional requirements into the statutory framework for private plaintiffs wishing to pursue a claim. ${ }^{64}$ In addition to the substantive requirements, a private claim must establish the elements of reliance, economic loss, and causation. ${ }^{65}$ These judicially created, private actionspecific elements have often been cited as justification for instituting and upholding a higher standard for extraterritorial application of the securities laws in private actions. $^{66}$

In the search for the appropriate standard for extraterritorial application of the securities laws to private transnational actions, certain policy considerations perpetuate the discussion. The main policy concerns are as follows: international comity, resource allocation, efficiency, investor protection, and availability of remedies. ${ }^{67}$ Virtually any discussion of extraterritoriality of the securities laws is incomplete without an analysis of the effects a given approach has on these policy concerns. Notably, such policy concerns are a significant, if not the primary, factor in the distinction between F-Squared actions, where the involvement of United

\footnotetext{
${ }^{62}$ The distinction between the two types of private transnational claims exists in the plaintiff party or class. F-Squared actions are brought by entirely domestic plaintiff(s), while F-Cubed actions are instituted by wholly or partly foreign plaintiff(s). See Kantor, supra note 5.

${ }^{63}$ See Stoneridge Inv. Partners v. Scientific-Atlanta, Inc., 552 U.S. 148, 152-54 (2008); Brief for the United States, supra note 36, at 25.

${ }^{64}$ See Stoneridge, 128 S. Ct. at 768; Brief for the United States, supra note 36, at 25-26.

${ }^{65}$ See Brief for the United States, supra note 36, at 26; Sarah S. Gold \& Richard L. Spinogatti, Applicability to SEC of Private Action Requirements in $\$ 10$ (b) Cases, 244 N.Y. L.J. 3 (2010), available at http://www.newyorklawjournal.com/PubArticleNY.jsp?id=1202464428352.

${ }^{66}$ See Brief for the United States, supra note 36, at 26; Kantor, supra note 4, at 841-66.

${ }^{67}$ Kantor, supra note 5, at 850-61; see also Brief for the United States, supra note 36, at 26-28.
} 
States investors lends stronger justification for application of the United States securities laws, and F-Cubed actions, where the policy concerns are often used to reject extraterritoriality where foreign investors are involved. ${ }^{68}$ Recognizing the importance of these specific policy concerns, the SEC explicitly instructed those submitting comments under the $\S 929$ Y study to include discussion of the potential effects of proposed standards for private actions on such policy concerns. ${ }^{69}$

The two most commonly cited standards for application to private transnational securities claims, the transactional test as announced in Morrison and the modified conduct-and-effects test as announced for public actions in $\S 929 \mathrm{P}$ of Dodd-Frank, are discussed at length throughout this note. ${ }^{70}$ While it is possible to approach the issue of private actions by considering only these two standards, a thorough analysis should at least acknowledge the potential alternatives. In its amicus brief in Morrison, the United States first announced its recommended standard for private suits, which required a heightened level of conduct from public suits. $^{71}$ This "direct injury" standard remains a viable alternative that must be considered along with the other potential standards. Another possible approach is to deny application of the securities laws to private transnational securities actions, leaving enforcement solely to the SEC and international suits. Although this approach has not received much support, it is theoretically possible, especially considering the implied nature of the private actions and the strong policy concerns present. ${ }^{72}$ Lastly, there exists some support for an intermediate standard that would allow a private action to be brought by United States investors under the modified conduct-and-effects test, but not in F-Cubed situations, regardless of the relevant conduct or effects. ${ }^{73}$

\section{B. The SEC Study: The Comments Are in, Now It Is the SEC's Move}

As part of the $\S 929 \mathrm{Y}$ study, the SEC solicited comments from any interested parties regarding their opinions on the appropriate standard to be presented to Congress in January 2012. After setting a deadline of February 18, 2011 for receipt

\footnotetext{
${ }^{68}$ See, e.g., Kantor, supra note 5, at 841, 871-72.

${ }^{69}$ Request for Comments from SEC on Study on Extraterritorial Private Rights of Action 5-8 (Oct. 25, 2010) [hereinafter Request for Comments], http://www.sec.gov/rules/other/2010/34-63174.pdf.

${ }^{70}$ See supra Parts II \& III.

${ }^{71}$ Brief for the United States, supra note 36 , at 25-28.

${ }^{72}$ See supra notes 63-69.

${ }^{73}$ See infra note 78.
} 
PAGE

of these comments, the SEC received fifty-one submissions from interested parties. ${ }^{74}$ The parties offering comments included multiple foreign governments, the United States Chamber of Commerce, numerous public pension funds and investment houses, various law firms, a group of forty-two law professors, other academics, and an individual who had been personally harmed by securities fraud. $^{75}$ The recommendations in the comment letters can be grouped into three general categories. These categories consist of recommendations for maintaining the current standard of the transactional test, ${ }^{76}$ for extending the $\S 929 \mathrm{P}$ standard of a modified conduct-and-effects test, ${ }^{77}$ and for instituting a type of intermediate standard permitting only United States investors to pursue private transnational securities claims. $^{78}$

A clear minority of the commenting parties recommended the intermediate standard. ${ }^{79}$ While this standard initially appears to have its benefits, it is hard to imagine that the SEC would recommend such a standard and, even assuming it did, that Congress would choose to adopt such an approach. The theory behind the intermediate standard is that by allowing United States investors to pursue private actions through the antifraud provisions, the concerns of investor protection and

74 See Request for Comments, supra note 69 (explaining the process and deadline for submitting comments). For a list of all the parties submitting comments and links to the relevant documents, see SEC, Comments on Study on Extraterritorial Private Rights of Action, http://www.sec.gov/comments/4617/4-617.shtml (last modified Feb. 17, 2012).

${ }^{75}$ See Comments on Study on Extraterritorial Private Rights of Action, supra note 74.

${ }^{76}$ See, e.g., U.S. Chamber of Commerce Comments, supra note 60 (writing in support of what is described as the "transactional," or "bright line," test); Letter from Gov't of the U.K. to Elizabeth M. Murphy, Sec'y, SEC 3-4 (Feb. 11, 2011) [hereinafter Gov't of the U.K. Comments], http://www.sec.gov/comments/4-617/4617-4.pdf.

77 See, e.g., NASCAT Comments, supra note 59, at 2; Letter from Robert P. Bartlett, III et al. to Elizabeth M. Murphy, Sec'y, SEC 5 (Feb. 18, 2011) [hereinafter Forty-Two Law Professors' Comments] (comments by forty-two law professors recommending the extension of $\S 929 \mathrm{P}$ standard to private actions), http://www.sec.gov/comments/4-617/4617-28.pdf.

${ }^{78}$ See, e.g., Letter from Cal. State Teachers' Ret. Sys. et al. to Elizabeth M. Murphy, Sec'y, SEC 1 (Feb. 18, 2011) [hereinafter Cal. State Teachers' Ret. Sys. Comments], http://www.sec.gov/comments/ 4-617/4617-13.pdf (suggesting such an intermediate standard); Ohio Public Employees' Retirement System Comments, supra note 58, at 1-2 (same).

${ }^{79}$ Four comment letters recommended a private action available for U.S. investors only, with one of those letters being submitted by the Maryland State Retirement and Pension System, who also signed on to the California State Teachers' Retirement System Comments. See sources cited supra note 77; see also Letter from Comptroller of the State of N.Y. to Elizabeth M. Murphy, Sec'y, SEC (Feb. 18, 2011), http://www.sec.gov/comments/4-617/4617-11.pdf; Letter from Maryland State Ret. \& Pension Sys. to Elizabeth M. Murphy, Sec’y, SEC (Feb. 18, 2011), http:/www.sec.gov/comments/4-617/4617-9.pdf. 
availability of remedies would be addressed, considering the United States is concerned with these issues primarily for United States investors. ${ }^{80}$ Also, by limiting the claims to solely United States investors, significantly fewer judicial resources would be expended than by allowing a broader standard for private actions. ${ }^{81}$ Lastly, as the theory goes, this intermediate standard would not raise the same international comity concerns that a broader standard would, considering that all the United States is doing is providing a method of relief to its own citizens harmed by fraud or misrepresentation. ${ }^{82}$

The flaws in this approach are apparent given the inaccuracies in the policy analysis. The appropriateness of this intermediate standard should be considered in light of the overarching goals of the antifraud provisions of the securities law: fraud deterrence and investor protection. ${ }^{83}$ Protecting only U.S. investors does not advance this goal as well as proponents of the intermediate approach insist, as deterrence is best served when the fraudulent acts can lead to liability in situations beyond those in which only domestic investors are harmed. ${ }^{84}$ Also, the strict line drawn between domestic and foreign investors may not be the best method of achieving justice in situations involving securities fraud with a connection to the United States. Finally, and most importantly, the support for the proposition that international comity concerns are wholly non-existent where a United States investor is involved, yet they remain where a foreign investor is harmed even if the conduct-and-effects test would be met, is lacking. ${ }^{85}$ As a whole, this intermediate approach appears to mitigate certain effects of the other approaches but does not provide a legitimate solution, as it leads to insufficient investor protection as well as potential continuing concerns regarding international comity.

Maintenance of the current standard, the transactional test from Morrison, which is sometimes referred to as the "bright line" test, is supported by

\footnotetext{
${ }^{80}$ See Cal. State Teachers' Ret. Sys. Comments, supra note 78, at 6.

${ }^{81} \mathrm{Id}$.

${ }^{82}$ Id. at $13-14$.

${ }^{83}$ See Brief for the United States, supra note 36, at 6.

${ }^{84}$ See infra Part V.C.

${ }^{85}$ Compare Cal. State Teachers' Ret. Sys. Comments, supra note 78, at 13-14 (discussing reduced international comity concerns over the intermediate standard), with NASCAT Comments, supra note 59, at 5-7 (addressing the extent of comity concerns arising from extension of the $\S 929 \mathrm{P}$ standard), and Letter from AGEST Superannuation Fund et al. to Elizabeth M. Murphy, Sec'y, SEC 10-13 (Feb. 18, 2011) [hereinafter Superannuation Fund Comments] (same).
} 
PAGE

approximately one half of the remaining comment letters ${ }^{86}$ and is the standard the SEC is most likely to recommend. As expected, this approach was advocated by all of the foreign governments that submitted comment letters on the subject. ${ }^{87}$ Additionally, other notable parties supporting maintenance of the transactional test in their comment letters include the United States Chamber of Commerce, the European Union, and the international law firm White \& Case LLP. ${ }^{8}$ After consideration of the policy rationale behind this approach, as well as the identities of the proponents of such an approach, it becomes evident why it would be the preferred, and therefore the most likely, approach to be recommended by the SEC under $\S 929 \mathrm{Y}$.

The primary policy rationale in support of the maintenance of the transactional test is the same concern for international comity and sovereignty of foreign nations that was previously announced by the Supreme Court in Morrison. ${ }^{89}$ As described by the government of France, expansion of the private right of action would violate principles of international comity because such actions would "substantially interfer[e] with the sovereign interests, policies, and laws of other nations." 90 This concern has remained central to the issue of the applicable standard of extraterritoriality of the antifraud provisions of the securities laws for private actions throughout its recent history. The strong resistance to extending the private right of action, as presented by foreign nations in their comment letters, echoes the approach taken by many of the same nations in amicus briefs submitted to the Supreme Court in Morrison..$^{91}$ Generally, this approach emphasizes the interest foreign nations possess in regulation of their own companies and the important distinctions between their own laws and the United

\footnotetext{
${ }^{86}$ From my interpretations of the comment letters, approximately seventeen to twenty can be read to support this proposition, while the same number can be read to support the recommendation of a similar $\S 929 \mathrm{P}$ conduct-and-effects test for private actions. See Comments on Study on Extraterritorial Private Rights of Action, supra note 74.

${ }^{87}$ For an entire list of these foreign governments, which includes France, Australia, the Federal Republic of Germany, and the United Kingdom, see $i d$.

${ }^{88} I d$.

${ }^{89}$ See Gov't of the U.K. Comments, supra note 76, at 2-4; U.S. Chamber of Commerce Comments, supra note 60 , at $2-4,10-22$.

${ }^{90}$ Letter from Gov't of Fr. to Elizabeth M. Murphy, Sec'y, SEC 3 (Feb. 17, 2011) [hereinafter Gov't of Fr. Comments], http://www.sec.gov/comments/4-617/4617-29.pdf.

${ }^{91}$ Morrison, 130 S. Ct. at 2885-86 ("[The foreign nations] all complain of the interference with foreign securities regulation that application of $\S 10(\mathrm{~b})$ abroad would produce, and urge the adoption of a clear test that will avoid that consequence.").
} 
States model for class action suits. ${ }^{92}$ The SEC, as a government agency, must remain acutely aware of the concerns of foreign nations in order to preserve relationships with other governments. The need for preservation of such relationships, from both a governmental policy and a practical perspective, is magnified in a field such as securities law where solely domestic issues are becoming increasingly less common. ${ }^{93}$ In the United States amicus brief endorsed by the SEC in Morrison, the Commission stressed the greater comity concerns presented by private actions while noting that such concerns were lessened or absent in the case of public actions. ${ }^{94}$ While the issue of international comity and the concerns of foreign nations are not determinative for the SEC's recommendation, their role in the decision-making process is undeniable.

Another significant policy consideration that factors into the determination of the applicable standard for private actions is a result of the explicit grant of authority for public actions in $\S 929 \mathrm{P} .^{95}$ By reaffirming the authority of the SEC and DOJ to institute public actions, Congress has assured the SEC that its power will subsist no matter what standard is adopted for private actions. The parties supporting the transactional test in their comment letters appear notably more confident in the effect of public enforcement of the antifraud provisions of the securities laws than the parties suggesting alternative standards. ${ }^{96}$ The United States Chamber of Commerce describes the public enforcement mechanisms as

${ }^{92}$ In its comment letter, White \& Case reiterates a point made by the United Kingdom and Northern Ireland in their amicus briefs in Morrison that "nations have a strong interest in regulating their own capital markets, developing disclosure rules to govern their own issuers, deciding how and when class action shareholder litigation should occur and determining the penalties for violations of such laws." Letter from White \& Case LLP to Elizabeth M. Murphy, Sec'y, SEC 3 (Feb. 17, 2011), http://www.sec.gov/comments/4-617/4617-3.pdf.

${ }^{93}$ See, e.g., Letter from Richard W. Painter, Professor of Corporate Law, Univ. of Minn. Law School, to Elizabeth M. Murphy, Sec'y, SEC 1-2 (Feb. 17, 2011) (supporting the transactional test based in part on "the fact that diplomatic and other disruption caused by f-cubed securities litigation could make it very difficult for the SEC to get cooperation from foreign securities regulators to pursue transnational securities fraud"), http://www.sec.gov/comments/4-617/4617-7.pdf.

${ }^{94}$ Brief for the United States, supra note 36, at 26-27.

${ }^{95}$ U.S. Chamber of Commerce Comments, supra note 60 , at 2, 5-8 ("Our country has the toughest administrative enforcement of securities laws in the world, and the [SEC and DOJ] received new, express extraterritorial enforcement authority in Section 929P.").

${ }^{96}$ Compare id. at 24-26 (“[P]ublic enforcement is more effective than private securities litigation."), with Letter from London Pensions Fund Auth. et al. to Elizabeth M. Murphy, Sec'y, SEC 2 (Feb. 18, 2011) [hereinafter London Pensions Funds Comments] ("No one disputes that the limited resources available to the Commission renders the private enforcement of the federal securities laws a necessary tool to combat the scourge of securities fraud."), http://www.sec.gov/comments/4-617/4617-39.pdf. 
"far-reaching and potent," 97 while the government of the United Kingdom classifies the ability to bring public actions as "the necessary powers to pursue cross-border securities fraud." ${ }^{, 98}$ An SEC view of its own enforcement powers would presumably be comparable to these descriptions, as the Commission has previously endorsed its preference for public actions over private actions. ${ }^{99}$ With such a positive view of the effectiveness of public actions in deterrence of securities fraud, the risks of rejecting expansion of the scope of private actions in order to address the international comity concerns appear minimal.

The justification for the transactional test also includes consideration of the cost-benefit analysis, as instructed under $\S 929 \mathrm{Y} .{ }^{100}$ According to proponents of this approach, the potential benefits of instituting a broader standard for private actions are generally limited to better compensation for injured investors, a benefit that appears unnecessary when viewed in light of the claimed effectiveness of public actions. ${ }^{101}$ This potential benefit appears even less significant when one is reminded that investors who purchase securities on United States exchanges are still afforded the ability to pursue a private action. Proponents of applying the transactional test to $\S 929 \mathrm{Y}$ view the costs of expansion of private actions as numerous, including unnecessary use of judicial resources, ${ }^{102}$ high costs to United States investors and businesses, ${ }^{103}$ and reduction of foreign direct investment (FDI) in United States capital markets. ${ }^{104}$ Again, in the government agency context in which the SEC operates, an approach which purports to preserve resources (both financial and administrative) while maintaining or promoting investment in domestic markets appears particularly appealing and thus furthers the likelihood of support by the Commission.

The analysis of the standard most likely to be chosen by the SEC would be incomplete without addressing why this standard is more probable than the direct-

${ }^{97}$ U.S. Chamber of Commerce Comments, supra note 60, at 2.

${ }^{98}$ Gov't of the U.K. Comments, supra note 76, at 7.

${ }^{99}$ See Brief for the United States, supra note 36, at 13-30.

${ }^{100}$ Dodd-Frank Act $\S 929 \mathrm{Y}(\mathrm{b})$.

${ }^{101}$ See U.S. Chamber of Commerce Comments, supra note 60, at 2, 5-8; Letter from Secs. Indus. \& Fin. Mkts. Ass'n \& Ass'n for Fin. Mkts. in Europe to Elizabeth M. Murphy, Sec'y, SEC, at 21-22 (Feb. 18, 2011), http://www.sec.gov/comments/4-617/4617-15.pdf.

${ }^{102}$ U.S. Chamber of Commerce Comments, supra note 60, at 22-24.

${ }^{103} \mathrm{Id}$.

${ }^{104} I d$. at 33-40. 
injury test first recommended by the United States in its amicus brief in the Morrison case. ${ }^{105}$ Notwithstanding the justification for the transactional test, the common-sense presumption exists that the test explicitly endorsed by the SEC previously would remain preferable. However, it is important to note that this standard was not supported by any of the numerous comment letters that were submitted to the Commission. ${ }^{106}$ While the SEC is in no way bound to select a recommendation based on these comment letters, the lack of support for the standard is at least relevant. In determining an appropriate standard to recommend, the SEC should consider the likelihood of Congress adopting the standard. Without any support from the commenting parties, the SEC would be hard-pressed to convince Congress through its recommendation that the direct-injury test was appropriate. Additionally, that same amicus brief suggested what is basically the standard adopted in $\S 929 \mathrm{P}$ for public action. ${ }^{107}$ If Congress had deemed that the SEC's opinion on the appropriate standard for private actions, standing alone, was sufficient to adopt the direct-injury test, why not simply adopt that standard in $\S 929$ Y initially? By requiring the study mandated in $\S 929 \mathrm{Y}$, Congress seems to have desired a stronger basis for determining the appropriate scope of private actions. Unless the remainder of the SEC study compiles convincing evidence supporting the direct-injury test, that standard is unlikely to surpass the transactional test as the Commission's ultimate recommendation to Congress under $\S 929$ Y.

\section{The Need for a Broader Private Action: Why the SEC Should Recommend the Extension of the Section 929P Standard to Private Actions}

The beneficial features of the transactional test for private actions are well documented, ${ }^{108}$ but careful consideration of the policy concerns and effects of the potential standards reveals that extension of the $\S 929 \mathrm{P}$ public action standard to private actions is the best possible approach. The quantity of parties submitting comment letters reaching this realization is comparable to those recommending the transactional test. ${ }^{109}$ The parties recommending extension of the $\S 929 \mathrm{P}$ standard include a group of forty-two law professors, domestic and international public

\footnotetext{
${ }^{105}$ Brief for the United States, supra note 36, at 25-28.

${ }^{106}$ See Comments on Study on Extraterritorial Private Rights of Action, supra note 74.

${ }^{107}$ Compare Brief for the United States, supra note 36, at 13-25, with Dodd-Frank Act § 929Y(b).

${ }^{108}$ See supra Part V.B.

${ }^{109}$ See supra note 86 .
} 
pension funds, various other institutional investors, and the National Association of Shareholder and Consumer Attorneys. ${ }^{110}$ The superior level of investor protection and fraud deterrence offered by application of the modified conduct-and-effects test in $\S 929 \mathrm{P}$ to private actions is both desirable and attainable. The protection offered by public actions alone is insufficient, ${ }^{111}$ and the international comity concerns with instituting such a standard, while present, are inflated by proponents of the transactional test. ${ }^{12}$ And while certain increased costs would be an unavoidable reality in instituting a broader private action, the benefit of significant protection for investors cannot be outweighed by frugality. Although unlikely to prevail as the Commission's recommended standard or as the standard ultimately adopted by Congress, the extension of the $\S 929 \mathrm{P}$ standard to private actions remains the most appropriate approach.

The extension of the $\S 929 \mathrm{P}$ standard to private actions would allow the SEC and private litigants to achieve enhanced results in the deterrence of fraud and protection of investors. ${ }^{113}$ This complimentary relationship, in which the United States is enforcing the public interest while private litigants are actively seeking compensation for harm, is a far more effective approach than conferring sole enforcement power on the limited resources of the government. ${ }^{114}$ Even if one accepts the claims by proponents of the transactional test that SEC enforcement is more effective than private action, ${ }^{115}$ there is no substitute for the deterrent effect from the potential for enhanced liability through a broader private action. ${ }^{116}$ Under the current standard, a company can take solace in the frightening truth that it can only be held liable under the antifraud provisions of the United States securities

\footnotetext{
${ }^{110}$ See Comments on Study on Extraterritorial Private Rights of Action, supra note 74.

${ }^{111}$ See London Pension Funds Comments, supra note 96; Letter from Kirby McInerney LLP to Elizabeth M. Murphy, Sec'y, SEC, at 7-8 (Feb. 17, 2011) (describing the SEC as "underbudgeted, understaffed, overburdened"), http://www.sec.gov/comments/4-617/4617-33.pdf.

${ }^{112}$ See Letter from DRRT to Elizabeth M. Murphy, Sec'y, SEC, at 3-4 (Feb. 15, 2011) [hereinafter DRRT Comments], http://www.sec.gov/comments/4-617/4617-2.pdf; NASCAT Comments, supra note 58 , at $5-9$.

${ }^{113}$ London Pension Funds Comments, supra note 96, at 2-3.

${ }^{114}$ See id.; DRRT Comments, supra note 112, at 2-3; Superannuation Fund Comments, supra note 85, at 6-8 ("It is unrealistic to expect that the SEC has the resources to police all securities frauds on its own. If the SEC is authorized under Dodd-Frank to police transactional frauds, it is essential that investors be given a private right of action to supplement the SEC's efforts."), http://www.sec.gov/ comments/4-617/4617-42.pdf.

${ }^{115}$ See supra notes 95-99.

${ }^{116}$ DRRT Comments, supra note 112, at 2-4.
} 
laws if its securities are listed on a domestic exchange, its securities are part of a domestic purchase, or its actions are so detrimental or offensive that the SEC chooses to apply its limited resources to institute a suit. Those who support maintenance of the current standard frame this issue as a positive aspect, as it allays the fears of foreign companies that they will be somewhat unknowingly subjected to a suit under United States securities laws. ${ }^{117}$ Unfortunately, in promoting this desirable but secondary benefit, the current standard is performing inadequately in achieving the primary goal of the antifraud provisions of the securities laws. ${ }^{118}$ By extending the scope of private actions under the modified conduct-and-effects test, the focus would be appropriately returned to the deterrence of fraud and protection of investors.

The most common justification for rejection of an extension of the scope of private actions is the international comity concerns that arise from extraterritorial application of the securities laws. ${ }^{119}$ The general approach advanced by foreign nations, as shown by the comment letters submitted to the SEC, ${ }^{120}$ is overwhelmingly in favor of maintaining the current limited standard of extraterritorial application. However, any assumption that a comparable private action standard to $\S 929 \mathrm{P}$ is so contrary to international comity as to require rejection of such a standard is premature. It is important for one to remember that the effect of $\S 929 \mathrm{P}$ is to institute a modified conduct-and-effects test for public actions. ${ }^{121}$ By extending this standard to private actions, the ability of private litigants to bring primarily foreign-based suits would remain limited to instances of significant domestic conduct or substantial domestic effects. ${ }^{122}$ Such a standard does not implicate the concerns assumed to be inherent in the original, broad conduct and effects tests. ${ }^{123}$ The narrower scope of this test ensures that a material component of the fraud, in the form of either significant conduct or foreseeable substantial effects, is domestic and thus does not raise the same policy concerns as

${ }^{117}$ E.g., U.S. Chamber of Commerce Comments, supra note 60, at 4, 33-38.

${ }^{118}$ See supra notes $113-14$.

${ }^{119}$ See supra notes 89-94.

${ }^{120}$ See supra notes $86-87$ and accompanying text.

${ }^{121}$ Dodd-Frank Act § 929P(b).

${ }^{122}$ Id.; see also NASCAT Comments, supra note 59, at 5.

${ }^{123}$ See NASCAT Comments, supra note 59, at 5-7 (explaining why "international relations will not be disturbed by allowing private investors to pursue securities fraud claims in the limited situations involving transnational fraud ... when significant conduct occurs in the United States or has substantial effects on investors in the United States"); Superannuation Fund Comments, supra note 85, at 10-13. 
pure extraterritorial application of United States laws. ${ }^{124}$ As such, the minimized comity concerns must be balanced with the enhanced investor protection and deterrence benefits.

Additionally, those with concerns surrounding the effects of a broader standard for private actions on foreign nations must also consider the related issue that a comparable standard to $\S 929 \mathrm{P}$ would permit private actions that are not limited to United States investors. ${ }^{125}$ All nations, albeit to varying degrees, possess and pursue an interest in deterrence of securities fraud and protection of investors. ${ }^{126}$ By expanding the scope of the private right of action to that of $\S 929 \mathrm{P}$, the United States would not be sacrificing the sovereignty of foreign nations for the sake of compensating its own investors, but rather providing remedies for both foreign and domestic investors for harm caused by fraudulent activities with an adequate level of connection to the United States. ${ }^{127}$ To ensure the adequacy of this connection, Congress has chosen language instituting the modified conduct-andeffects standard over the original. ${ }^{128}$ When the potential inadequacy of available remedies for both domestic and foreign investors abroad is also considered, ${ }^{129}$ the extension of private right of action is revealed as a necessary method of promoting and enforcing an international goal rather than an infringement on principles of international comity and sovereignty. ${ }^{130}$

\footnotetext{
${ }^{124}$ It is important to distinguish that while nations ideally would like their laws to apply in most, if not all situations, true international comity concerns in this area arise from attempted application of United States laws where there is an insufficient connection to the United States. So, while the foreign nations' comment letters logically support the transactional test as an opportunity to have claims arise only under their law for a greater number of disputes, the true comity concern is not evident in permitting any claims beyond those permitted by such a test. For discussion of why these comity concerns are lessened by this narrow scope, see sources cited supra note 123.

${ }^{125}$ Contra supra notes $78-82$ and accompanying text.

${ }^{126}$ This policy concern and the methods of enforcement are discussed throughout the comment letters submitted to the SEC. See Comments on Study on Extraterritorial Private Rights of Action, supra note 74.

${ }^{127}$ See supra note 123. See also DRRT Comments, supra note 112; London Pensions Fund Comments, supra note 96, at 2 ("Such private lawsuits promote public and global confidence in our capital markets and help to deter wrongdoing and to guarantee that corporate officers, auditors, directors, lawyers and others properly perform their jobs.").

${ }^{128}$ Dodd-Frank Act $\S 929$ P. For a discussion of this modified standard, see Brief for the United States, supra note 36.

${ }^{129}$ See NASCAT Comments, supra note 59, at 24-30; DRRT Comments, supra note 112, at 3.

${ }^{130}$ See NASCAT Comments, supra note 59, at 8-10.
} 
From a cost-benefit perspective, the superiority of the modified conduct-andeffects test over the transactional test is apparent. The risks of extending a private right of action comparable to $\S 929 \mathrm{P}$ exist primarily in the economic and judicial resource concerns. ${ }^{131}$ Regarding judicial resources, the costs are mitigated by the limitations inherent in the requirements of significant conduct or foreseeable substantial effects, as much of the potential for frivolous suits present with the general conduct and effects standards is reduced. ${ }^{132}$ Also, various judicial mechanisms are available to aid in the reduction of the amount of judicial resources expended for private actions lacking merit. ${ }^{133}$ The perceived economic risks of extension of the private right of action, mainly that the threat of private action would deter companies from doing business in the United States and reduce FDI, are at least equaled by the economic benefits offered to the United States financial markets. In the current global economy, where securities are routinely purchased on foreign exchanges arbitrarily by United States investors, ${ }^{134}$ where the practice of cross-listed securities is prevalent, ${ }^{135}$ where United States institutional investors are functionally required to invest in foreign securities, ${ }^{136}$ and where investor protections in foreign nations are uncertain, ${ }^{137}$ the importance of the benefits provided to investors under a standard for private actions comparable to $\S 929 \mathrm{P}$ is immeasurable. Lastly, while the transactional test has received praise from some for its predictability, ${ }^{138}$ the necessity for the courts to determine the relevant interpretation of the $\S 929 \mathrm{P}$ standard, as applicable to public actions, already exists as the legislation has only recently been enacted. Therefore, by extending this standard to private actions, predictability would actually be increased, as

\footnotetext{
${ }^{131}$ See supra Part V.B.

${ }^{132}$ See Superannuation Fund Comments, supra note 85, at 13-14 (discussing effect of the limits imposed by involvement of a "material domestic component"); NASCAT Comments, supra note 59, at 10 ("Section 929P itself includes limits that preclude the prosecution of ... claims that have an insignificant connection to the U.S.”).

${ }^{133}$ Examples of these available judicial tools, in addition to a determination of a lack of sufficient domestic connection, include forum non conveniens, dismissal for lack of subject matter jurisdiction under Fed. R. Civ. P. 12(b)(1). See NASCAT Comments, supra note 59, at 9-11.

${ }^{134}$ Forty-Two Law Professors' Comments, supra note 77, at 7.

${ }^{135}$ Id. at $9-10$.

${ }^{136}$ NASCAT Comments, supra note 59, at 14.

${ }^{137}$ Id. at 23 .

${ }^{138}$ E.g., Gov't of Fr. Comments, supra note 90, at 5.
} 
U N I V E R S I T Y O F P I T T S B U R G H L A W R E V I E W

\begin{tabular}{l|lll|llllll}
\hline P A G E & 422 & V O L U M E 73 & 3
\end{tabular}

transnational securities actions, whether public or private, would be governed by one common standard rather than the current dual-standard approach.

\section{Conclusion}

The extraterritorial application of the antifraud provisions of the Exchange Act is a complicated issue that affects numerous constituents and, not surprisingly, is the subject of passionate disagreement. The issue appeared sufficiently settled by years of analysis by the circuit courts but was upended by the Morrison decision, which was subsequently altered by Dodd-Frank. Unfortunately, the state of private transnational securities actions will not be settled until well after the January 2012 deadline for the $\S 929$ Y SEC study. At the present time, the SEC study appears likely to include a recommendation for the maintenance of the transactional test as the standard for private actions, based on conceptions of international comity concerns and the sufficiency of public action under §929P. However, this recommendation should place proper emphasis on the goals of investor protection and fraud deterrence, and recommend extension of the $\S 929 \mathrm{P}$ standard and its modified conduct-and-effects test to private actions in lieu of the transactional test. 